\title{
Genotypic Differences and Nitrogen Uptake of Lowland Rice (Oryza sativa L.) under Two Production Systems and N Application
}

\author{
Mark Joshua S. Quevedo $^{1 *}$, Ruth O. Escasinas ${ }^{2}$ and Dionesio M. Bañoc ${ }^{3}$
}

\section{ABSTRACT}

Climate change has been causing low yield in rice production. In order to counter the negative effects of climate change in rice production, it is important to choose a suitable variety and production system, as well as application of nitrogen. This study sought to determine the agronomic and yield performance of inbred and hybrid rice under System of Rice Intensification (SRI) and conventional production systems, as well as evaluate the Nitrogen Use Efficiency (NUE) of these varieties under two production systems and $\mathrm{N}$ application. The experiment was laid out in a nested design in RCBD with varieties as the main plot and $\mathrm{N}$ application as subplot ( $0 \mathrm{~kg} \mathrm{~N} \mathrm{ha}^{-1}$ and $90 \mathrm{~kg} \mathrm{~N} \mathrm{ha}^{-1}$ ) under two production systems. Inbred rice grown under SRI headed earlier than hybrid rice in similar condition and both varieties in the conventional production system. Irrespective of production system, hybrid variety and those applied with $\mathrm{N}$ were taller than inbred without $\mathrm{N}$ application. Regardless of the variety and levels of $\mathrm{N}$ applied, lowland rice grown under SRI produced the most productive tillers, heaviest 1,000 grains, heaviest root pulling resistance (RPR), and highest leaf area index(LAI). In terms of $\mathrm{N}$ levels, grain yield was higher when 90 $\mathrm{kg}$ of $\mathrm{N}$ was applied in both production systems than without $\mathrm{N}$. Both varieties had comparable grain yield when applied with $90 \mathrm{~kg} \mathrm{~N} \mathrm{ha}^{-1}$. Highest NUE was obtained under SRI with application of $90 \mathrm{~kg} \mathrm{~N} \mathrm{ha}^{-1}$ and under conventional system without $\mathrm{N}$ application. Thus, rice grown under SRI had better utilization of applied $\mathrm{N}$. Meanwhile, water supplied in SRI was reduced by $32 \%$ compared to the conventional production system.

Keywords: hybrid rice, inbred rice, Nitrogen Use Efficiency (NUE), System of Rice Intensification (SRI)

\section{INTRODUCTION}

Rice (Oryza sativa L.) is mostly consumed as a staple food in large parts of the world especially in Asia and provides $35-60 \%$ of the calories in the diet of three billion people (Redfern et al 2012).

In the Philippines, rice production is faced with the rising cost of inorganic fertilizers and the growing constraints in the availability of irrigation water due to

\footnotetext{
${ }^{1}$ Office of the Graduate School, Visayas State University, Baybay City, Leyte, Philippines

${ }^{2,3}$ Department of Agronomy, Visayas State University, Baybay City, Leyte, Philippines 


\section{Genotypic Differences and Nitrogen Uptake of Lowland Rice}

climate change. Hence, there is a need to find ways to increase rice production with a reduced amount of irrigation water and increased nitrogen use efficiency. $\mathrm{N}$ is the most limiting nutrient in rice production (Haefele et al 2006). Its addition is important in increasing farm productivity. Ensuring sufficient $\mathrm{N}$ supply at the right amount and at the right time to crops is necessary to achieve optimum yields. However, farmers tend to apply excessive amounts. Excess application favors pest and diseases incidence, increase soil degradation, and decrease nitrogen use efficiency (NUE) resulting in low yield (Wood et al 2004). NUE, however, largely depends on water availability, solar intensity, soil quality, crop management, and the crop's varietal characteristics.

New inbred rice varieties have a relatively high ratio of grain yield to total dry matter and have higher grain yields per unit of $\mathrm{N}$ uptake (Hütsch and Schubert 2017). Similarly, hybrid rice produces $15-20 \%$ higher grain yield compared to inbred rice provided the required optimum conditions are met (Haque et al 2015). However, the yield level is still unstable due to differences in NUE.

Modification of rice production systems like the System of Rice Intensification (SRI) is gaining popularity in South East Asia as seed, water, and cost requirements in this system are reduced to $80-90 \%, 25-50 \%$, and $10-20 \%$, respectively. It also increased the efficiency of both water and $\mathrm{N}$ fertilizer applied (Zhao et al 2009). This could be a promising alternative to the conventional rice production systems which require higher farm inputs. Hence, the study aimed to determine the agronomic yield and yield components of inbred and hybrid rice varieties under SRI and conventional rice production systems with and without $\mathrm{N}$ application; and evaluate the NUE of inbred and hybrid rice with $\mathrm{N}$ application under SRI and conventional production system.

\section{MATERIALS AND METHODS}

\section{Land Preparation}

An area of $720 \mathrm{~m}^{2}$ was prepared by soaking the field for four (4) weeks, followed by harrowing using a hand tractor. The field was flooded again and final rotavation was done one (1) week before transplanting. The field was then leveled using a carabao drawn levelling board and drained before transplanting.

\section{Soil Sample Collection and Soil Sample Analysis}

After land preparation, there were ten soil samples collected from a depth of 20 $\mathrm{cm}$ of each experimental field. The collected soil samples were composited, airdried, and sieved using a 2-mm wire mesh. The soil samples were submitted to the Central Analytical Services Laboratory (CASL), PhilRootcrops Complex, VSU, Visca, Baybay City, Leyte, Philippines. Samples were analyzed based on soil $\mathrm{pH}$ (Potentiometric method at $1: 1$ soil water ratio PCARR 1980), percentage (\%) organic matter (Modified Walkley and Black method, ISRIC 1995), total N (Kjeldahl method, Nelson and Sommers, 1982), available P (Olsen's method, Olsen et al 1954), and exchangeable $\mathrm{K}$ content (ammonium acetate extraction method, ISRIC 1995). For final soil analysis, five soil samples were collected after harvest per treatment plot and composited. These were submitted to CASL for analysis of the 
same aforementioned parameters.

\section{Experimental Design}

The experiment was laid out in nested design in RCBD with three (3) replications. The varieties (inbred and hybrid) comprised the main plot and $\mathrm{N}$ rates ( 0 and $90 \mathrm{~kg} \mathrm{~N} \mathrm{ha}^{-1}$ ) as the subplot nested within two production systems (SRI and Conventional). A total of 24 subplots measuring $4 \mathrm{~m} \times 5 \mathrm{~m}$ were made with 20 rows of rice hills per plot in both production systems. To facilitate farm operations, management and data gathering, replication and mainplots were separated by onemeter alleyways and subplots by $0.5 \mathrm{~m}$ alleyways. Levees of $30.5 \mathrm{~cm}$ were constructed around each plot to avoid contamination of nutrients from one plot to another.

The different treatments were designated as follows:

A. Production Systems

$\mathrm{E}_{1}-\mathrm{SRI}$ (System of Rice Intensification)

$\mathrm{E}_{2}$ - Conventional method

Within production systems, the treatments were as follows:

B. Mainplot

$\mathrm{V}_{1}$ - Inbred (NSIC Rc216)

$\mathrm{V}_{2}$ - Hybrid (SL-18H)

C. Subplot (Napplication)

$\mathrm{N}_{1}-0 \mathrm{~kg} \mathrm{ha}^{-1}$

$\mathrm{N}_{2}-90 \mathrm{kgha}^{-1}$

\section{Seedbed Preparation and Transplanting}

The seedbed was prepared a day before sowing. Four wetbeds (two wetbeds for $E_{1}$ and $E_{2}$ ) measuring $2 \mathrm{~m} \times 5 \mathrm{~m}$ long with drainage canals were constructed in separate areas to avoid obstruction in the preparation of the experimental plots. After that, soaking and sowing of seeds in the conventional method were done four (4) days ahead of those in SRI. Approximately $2 \mathrm{~kg}$ of inbred (RC 216) and hybrid (SL$18 \mathrm{H}$ ) were soaked in fresh water for $24 \mathrm{~h}$ and incubated for $43 \mathrm{~h}$. Pre-germinated seeds were sown in the seedbed and application of complete fertilizer was done at a rate of one tbsp per $\mathrm{m}^{2}$. Proper management and weed control were employed until the seedlings were ready for transplanting.

For SRI, transplanting of ten day-old seedlings (or at 2-3 leaf stage) at one seedling per hill was done by carefully removing the seedlings along with the soil to avoid root injury. A planting distance of $20 \mathrm{~cm} \times 20 \mathrm{~cm}$ was used.

In the conventional method, fourteen-day old seedlings were transplanted at a rate of three (3) seedlings per hill. The distance of planting was $20 \mathrm{~cm} \times 20 \mathrm{~cm}$. Missing hills were replanted within seven (7) days after transplanting.

\section{Preparation and Application of Fertilizer}

Urea, solophos, and muriate of potash were the fertilizer used. All $\mathrm{N}_{1}$ plots were applied only with $60 \mathrm{~kg} \mathrm{ha}^{-1} \mathrm{P}_{2} \mathrm{O}_{5}$ and $\mathrm{K}_{2} \mathrm{O}$, while all $\mathrm{N}_{2}$ plots were applied with $90-60-60$ $\mathrm{kg} \mathrm{ha}^{-1} \mathrm{~N}, \mathrm{P}_{2} \mathrm{O}_{5}$, and $\mathrm{K}_{2} \mathrm{O}$. All amounts of $\mathrm{P}$ and $\mathrm{K}$ were applied basally 12 days after 


\section{Genotypic Differences and Nitrogen Uptake of Lowland Rice}

transplanting (DAT). The $\mathrm{N}$ was applied in two splits; at basal and panicle initiation (43 DAT), wherein the first split was $60 \mathrm{~kg} \mathrm{~N} \mathrm{ha}^{-1}$ at early tillering stage (12DAT) and the second split was $30 \mathrm{~kg} \mathrm{~N} \mathrm{ha}^{-1}$ at panicle initiation stage (43 DAT). Application of $\mathrm{N}$ fertilizer was made with adequate water to minimize $\mathrm{N}$ loss.

\section{Weed Management and Pest Control}

In SRI treatment, each plot was rotary weeded at 10 DAT. Rotary weeding promotes aeration of the soil and incorporates weeds for a possible nutrient cycle. Rotary weeding operations were done four times during 22 DAT, 35 DAT, 45 and 55 DAT.

In the conventional method, the first rotary weeding was done at 18DAT. Second weeding followed 32 DAT, followed by spot hand-weeding. Succeeding weeding operation was done at 46 DAT.

Spraying of panyawan-based (Tinosporarumphii Boerl.) botanical pesticide was done to control green leaf hopper (Nephotettix nigropictus Stal) and rice bugs (Leptocorisa acuta).

\section{Water Management}

This study was conducted during the onset of the dry season (February to May). The total volume of irrigation water applied throughout the study was calculated using the following:

a. Measurement of flow rate using bucket method - an inlet was created from the main canal going to each treatment plot. At the end of the inlet, a bucket/container (2L capacity) was placed to collect the flowing water from the inlet. The time spent until the bucket was filled with water was recorded. Flow rate $(\mathrm{Q})$ was calculated by dividing the volume of water in the container $(v)$ by the time $(t)$ the container was filled with water. The procedure was repeated three times, and then the average flow rate $\left(Q_{\text {ave }}\right)$ was calculated using the following formula:

$$
\begin{aligned}
& \mathrm{Q}=\frac{\text { Volumeof water filled in the container }(v) \text {, }}{\text { Time }(t) \text { spent in filling } t \square e \text { container,sec }} \\
& \mathrm{Q}_{\mathrm{ave}}=\frac{\text { TotalQ }}{\text { No. oftrials }}
\end{aligned}
$$

Where:

$$
\begin{aligned}
& \mathrm{Q}=\text { flow rate, } \mathrm{li} / \mathrm{sec} \\
& \mathrm{Q}_{\text {ave }}=\text { average flow rate, li/sec }
\end{aligned}
$$

a. Measurement of the total volume of water supplied was determined by calculating the average flow rate and recording the time incurred in the initial $\left(T_{0}\right)$ and final time $\left(T_{f}\right)$ during irrigation.

The total volume of water supplied was calculated using the following formula: $\mathrm{V}=\mathrm{Q}_{\text {ave }}\left(\mathrm{T}_{\mathrm{f}}-\mathrm{T}_{0}\right)$ 
Where:

$$
\begin{aligned}
& V=\text { total volume supplied, li } \\
& Q_{\text {ave }}=\text { average flow rate, li/sec } \\
& T_{f}=\text { final time upon irrigating, sec } \\
& T_{0}=\text { initial time upon irrigating, sec }
\end{aligned}
$$

In SRI, the field was left without flooding for at least 12 days after transplanting and followed by alternate wetting and drying (AWD) until flowering stage (42 DAT). The field was flooded for 3 days and then drained to the extent of surface cracking. When water level dropped to about $15 \mathrm{~cm}$ below the soil surface, irrigation water was then applied to a depth of $5 \mathrm{~cm}$ to reflood the field. The wetting and drying processes allowed the plant roots to grow well. In the reproductive stage however, a water level of $5 \mathrm{~cm}$ was maintained until two weeks before harvest. Throughout the study, the total number of irrigation frequency observed in SRI was 14 .

In the conventional method, the area was drained during transplanting. Irrigation was supplied 3DAT at 2 to $3 \mathrm{~cm}$ deep. During panicle initiation (43 DAT), water level was increased to a depth of 3 to $5 \mathrm{~cm}$ and was drained 2 weeks before harvest to facilitate harvesting. A total of 22 irrigation frequency was observed in the conventional method throughout the study.

During rainy days, the dikes were opened for easy drainage of rain water.

\section{Harvesting and Processing}

Harvesting was done when $85 \%$ of the grains in the panicle in each treatment plot had ripened. The panicles were cut near the base, threshed, dried to $14 \%$ moisture content, and winnowed before gathering all the necessary data.

\section{Data Gathered}

\section{Agronomic Characteristics}

1. Days from sowing to heading was recorded when $50 \%$ of the plants in each treatment plot exerted their panicle from the flag leaf sheath.

2. Days from sowing to maturity was recorded by counting the number of days from sowing to the time when $85 \%$ of the grains of the panicle were mature as shown by the firm and amber color of the grains.

3. Plant height $(\mathrm{cm})$ at maturity was determined by measuring the height of the ten sample hills in each treatment plot from ground level up to the tip of the tallest plant part before harvest.

4. Leaf Area Index (LAI) was determined by randomly selecting five sample hills in each treatment plot making sure that the hills are surrounded by living hills. The number of tillers for each sample hill in each treatment plot was counted and the middle tiller was identified (Gomez and Gomez 1984). The length and width (broadest part) of each leaf from middle tiller of each sample hill was measured and the area of each leaf was computed using the formula:

Leaf area $=$ length $\times$ width $\times 0.75$ (Yoshida 1981) 


\section{Genotypic Differences and Nitrogen Uptake of Lowland Rice}

Leaf area per hill = total leaf area of middle tiller $x$ total number of tillers per hill

The Leaf Area Index (LAI) was computed using the formula below:

$$
\text { LAI }=\frac{\text { Sum of total leaf area per hill of } 5 \text { sample hills }}{\text { Area of land covered by } 5 \text { hills }\left(2,000 \mathrm{~cm}^{2}\right)}
$$

5. Fresh Straw yield $\left(\mathrm{t} \mathrm{ha} \mathrm{h}^{-1}\right)$ was collected in all sample plants in the harvestable area in each treatment plot by cutting all sample plants from the ground level, weighed, and converted to per hectare basis using the following formula:

$$
\text { Straw yield }\left(\mathrm{t} \mathrm{ha}^{-1}\right)=\frac{\text { Straw yield }(\mathrm{kg})}{\text { Harvestable area }\left(13.44 \mathrm{~m}^{2}\right)} \times \frac{10000 \mathrm{~m}^{2}}{1000 \mathrm{~kg}}
$$

6. Root pulling resistance (RPR) was measured using a $100 \mathrm{~kg}$ spring balance to determine the root strength at flowering stage $\left(\mathrm{O}^{\prime}\right.$ Toole and Soemartono 1981). The plant was tied up with a small rope attached to a spring balance and pulled to obtain the amount of force exerted in pulling the plant.

\section{Yield and Yield Components}

1. Number of productive tillers hill ${ }^{-1}$ at maturity was determined by counting the number of tillers hill ${ }^{-1}$ that developed panicles from ten sample hills in each treatment plot at maturity.

2. Weight of 1,000 grains (g) was obtained by weighing 1,000 grains from the same sample plants used for filled and unfilled spikelets count.

3. Grain yield $\left(\mathrm{t} \mathrm{ha}^{-1}\right)$ was determined by weighing the grains obtained from the harvestable area in each treatment plot. The grains were cleaned, sun-dried at $14 \% \mathrm{MC}$ and were converted into tons per hectare using the formula:

$$
\text { Grain Yield }\left(\mathrm{t} \mathrm{ha}^{-1}\right) \frac{\text { Plot yield }(\mathrm{kg})}{\text { Harvestable area }\left(13.44 \mathrm{~m}^{2}\right)}=\frac{10,000 \mathrm{~m}^{2} \mathrm{ha}^{-1}}{1,000 \mathrm{~kg} \mathrm{t}^{-1}}
$$

\section{Nitrogen Use Efficiency}

Tissue $\mathrm{N}$ analysis for grain and straw samples was done after oven-drying at $70^{\circ} \mathrm{C}$ for three days until constant weight was attained. The samples were then ground to pass through a $0.5 \mathrm{~mm}$ sieve using a Willey mill. $\mathrm{N}$ content in the grains and straw was determined separately by digesting the samples in concentrated sulfuric acid, followed by analysis for total $\mathrm{N}$ using the micro-Kjeldahl method (Yoshida et al 1976). Total aboveground plant $\mathrm{N}$ uptake was calculated based on tissue $\mathrm{N}$ concentration and the quantity of grain and straw. 
The NUE parameter was computed using the following formula;

a). internal or physiological NUE(IEN $)=\mathrm{GY} / \mathrm{TNU}$;

b). harvest index $(\mathrm{HI})=\mathrm{GY} /(\mathrm{GY}+\mathrm{SY})$,

where,

GY-grain yield

SY - straw yield

TNU - total aboveground plant N uptake (grain and straw N uptake)

Meteorological Data

Data on the total weekly rainfall $(\mathrm{mm})$, average temperature $\left({ }^{\circ} \mathrm{C}\right)$, minimum and maximum and relative humidity (\%) throughout the duration of the experiment were obtained from the PAGASA Station, VSU, Visca, Baybay City, Leyte.

\section{Statistical Analysis}

Analysis of variance was done using the computer software Statistical Tool for Agricultural Research (STAR). Mean comparison of parameters which showed significant differences was done using Tukey's test.

\section{RESULTS AND DISCUSSION}

\section{The Study Site}

The results of initial soil analysis revealed that the soil had a pH of 5.49 with $1.91 \%$ organic matter, $0.18 \%$ total $\mathrm{N}, 6.12$ available $\mathrm{P}\left(\mathrm{mg} \mathrm{kg}^{-1}\right.$ soil), and 0.26 exchangeable $\mathrm{K}$ (meq100 $\mathrm{g}^{-1}$ soil). These indicate that the soil $\mathrm{pH}$ is strongly acidic, very low in organic matter, low in both total $\mathrm{N}$ and available $\mathrm{P}$, and had medium extractable $\mathrm{K}$ (Landon 1991). The observed low amount of $\mathrm{pH}$, organic matter, $\mathrm{N}$ and $P$ could be due to the continuous planting of rice and excessive use of acidreleasing inorganic fertilizers like urea.

The total amount of rainfall throughout the experimental period was 704.20 $\mathrm{mm}$. The highest rainfall was noted in the second week after crop establishment with $281.00 \mathrm{~mm}$, and the lowest rainfall was recorded in the fifth week with $1.4 \mathrm{~mm}$. Thus, the total amount of rainfall was sufficient for crop growth, since the adequate rainfall requirement for rice production is $600-800 \mathrm{~mm}$ per month (Jehangir et al 2007). The maximum temperature recorded ranged from 27.50 to $32.55^{\circ} \mathrm{C}$ while the minimum temperature ranged from 22.23 to $26.20^{\circ} \mathrm{C}$. Optimal temperature for rice cultivation falls between 27 to $32{ }^{\circ} \mathrm{C}$ (Yin et al 1996), which indicates that the recorded temperature throughout the study was adequate. Likewise, relative humidity ranged from $75-89.33 \%$, which is favorable for rice production, as the optimal relative humidity requirement for rice production falls between $60-80 \%$ (Rathnayake et al 2016). 


\section{Volume of Water Supplied $\left(\mathrm{m}^{3} \mathrm{ha}^{-1}\right)$}

The total amount of water used was higher in the conventional rice production $\left(121,813.4 \mathrm{~m}^{3} \mathrm{ha}^{-1}\right)$, while in SRI, the total volume of water supplied was only $82,956.77 \mathrm{~m}^{3} \mathrm{ha}^{-1}$ (Table 1). The reduction of $32 \%$ in water supplied in SRI was observed. This result conforms with Satyanarayana et al (2006) which shows that SRI has the potential to reduce water requirements in rice production to about 25 to $50 \%$. Shi et al (2002) added that intermittent irrigation significantly reduces quantity of irrigation water by $27-37 \%$ compared to flooded rice production.

Table 1. Volume of water supplied $\left(\mathrm{m}^{3} \mathrm{ha}^{-1}\right)$ throughout the growing period of lowland rice as influenced by production systems

\begin{tabular}{lc}
\hline \multicolumn{1}{c}{ Treatment } & Total volume of water $\left(\mathrm{m}^{3} \mathrm{ha}^{-1}\right)$ \\
\hline SRI & $82,956.77$ \\
Conventional & $121,813.4$ \\
Difference (\%) & 32 \\
\hline
\end{tabular}

\section{Agronomic Parameters}

The statistical analysis revealed that the number of days from sowing to heading and maturity were significantly influenced by production systems and variety but not by the levels of $\mathrm{N}$ applied. Rice under SRI headed and matured earlier regardless of variety and levels of $\mathrm{N}$ (Table 2). However, interaction between production systems and variety was observed. Inbred rice headed earlier than hybrid rice under SRI but when grown under conventional method, inbred and hybrid rice headed at the same time (Table 3). This was similar to the findings of Krupakar Reddy (2004) and Kumar (2014) that lowland rice under SRI headed earlier than lowland rice planted in conventional system of production and may be attributed to the early transplanting of seedlings. This was also the same with the findings of Liu et al. (2017) that the younger seedling age greatly influenced early heading.

Hybrid rice grew taller than inbred rice and more evidently when applied with $\mathrm{N}$ fertilizer at $90 \mathrm{~kg} \mathrm{~N} \mathrm{ha}^{-1}$ than those without $\mathrm{N}$. This result could be due to the genetic superiority of the hybrid variety over that of the inbred variety in terms of plant height. This conforms with the findings of Huang et al(2012). The application of $\mathrm{N}$ at $90 \mathrm{~kg} \mathrm{ha}^{-1}$ enhanced stalk elongation because this favored translocation of more assimilates to the culm. Similar results of increased plant height due to $\mathrm{N}$ application were observed by Somasundaram et al (2002), Rahaman (2004), Chaturvedi (2005), and Moro et al (2015).

Similarly, regardless of variety, lowland rice produced significantly bigger LAI when applied with $\mathrm{N}$ under SRI. Jing et al (2007) noted a significant increase in LAI with $\mathrm{N}$ application. Moreover, the interaction between variety and production systems was observed (Table 4). Both inbred rice under SRI and conventional production system and hybrid rice in SRI had comparably higher LAI than hybrid rice in the conventional production system. LAI values could be related to higher plant population per hectare, which was observed under SRI. 
Quevedo, Escasinas and Bañoc

Table 2. Agronomic characteristics of lowland rice as influenced byproduction system, variety and $\mathrm{N}$ application

\begin{tabular}{|c|c|c|c|c|c|c|}
\hline \multirow{2}{*}{ Treatment } & \multicolumn{2}{|c|}{$\begin{array}{l}\text { No. of days from sowing } \\
\text { to }\end{array}$} & \multirow{2}{*}{$\begin{array}{l}\text { Plant } \\
\text { Height } \\
(\mathrm{cm})\end{array}$} & \multirow{2}{*}{ LAI } & \multirow{2}{*}{$\begin{array}{c}\text { Fresh } \\
\text { Straw yield } \\
\left(\mathrm{t} \mathrm{ha}^{-1}\right)\end{array}$} & \multirow{2}{*}{ RPR (kg) } \\
\hline & Heading & Maturity & & & & \\
\hline \multicolumn{7}{|l|}{ Production System } \\
\hline SRI & $74.33 b$ & $97.75 b$ & 114.42 & $9.40 \mathrm{a}$ & 6.52 & $40.11 \mathrm{a}$ \\
\hline Conventional & $78.58 \mathrm{a}$ & $104.83 \mathrm{a}$ & 114.21 & $6.80 \mathrm{~b}$ & 7.44 & $30.08 b$ \\
\hline \multicolumn{7}{|l|}{ Variety } \\
\hline Inbred(NSICRc 216) & $75.42 b$ & $100.67 b$ & $104.74 \mathrm{~b}$ & 7.45 & 6.51 & 34.44 \\
\hline Hybrid (SL-18H) & $77.50 \mathrm{a}$ & $101.92 \mathrm{a}$ & $123.88 \mathrm{a}$ & 8.74 & 7.45 & 35.75 \\
\hline \multicolumn{7}{|l|}{ Level of $N$} \\
\hline $0 \mathrm{kgha}^{-1}$ & 76.50 & 101.33 & $107.98 \mathrm{~b}$ & $6.61 \mathrm{~b}$ & $6.21 \mathrm{~b}$ & $32.03 \mathrm{~b}$ \\
\hline $90 \mathrm{kgha}^{-1}$ & 76.42 & 101.25 & $120.64 \mathrm{a}$ & $9.59 \mathrm{a}$ & $7.75 \mathrm{a}$ & $38.17 \mathrm{a}$ \\
\hline C.V.(\%) & 2.35 & 1.17 & 4.16 & 24.12 & 24.06 & 5.79 \\
\hline
\end{tabular}

Means with the same letter(s) are not significantly different at 5\% level, HSD

$\mathrm{N}$ fertilization significantly increased straw yield of rice. This could be due to the increased availability of $\mathrm{N}$ in the soil that enhances tiller formation and stalk elongation.

Root pulling resistance (RPR), on the other hand, differed significantly in both production systems and levels of $\mathrm{N}$ fertilization but not in varieties. The result conforms to the findings of SRI advocates (Trivedi 2006; Uphoff et al 2006; and Barison and Uphoff 2011), who reported that nodal roots tend to produce more lateral roots. Thus, more roots are anchored in the soil, which could be a consequence of the stress induced by the alternate wetting and drying in SRI (Zhang et al 2009). Greater RPR in N applied plants could also be attributed to the good root development brought about by the applied Nin the soil (Wu et al 2017 and Zhang et al 2020).

Table 3. Interaction effect between production system and variety on the number of days from sowing to heading of lowland rice

Variety

Days from sowing to heading

SRI Conventional

$\begin{array}{lll}\text { Inbred (NSIC Rc216) } & 72.33 \mathrm{~b} & 78.50 \mathrm{a} \\ \text { Hybrid (SL-18H) } & 76.33 \mathrm{a} & 78.67 \mathrm{a}\end{array}$

Means followed by a common letter(s) across production system and variety are not significantly different at $5 \%$ level, HSD. 


\section{Genotypic Differences and Nitrogen Uptake of Lowland Rice}

Table 4. Interaction effect between production system and variety on leaf area index (LAI) of lowland rice

\begin{tabular}{lccc}
\hline & \multirow{2}{*}{ Variety } & \multicolumn{2}{c}{ LAI } \\
\cline { 2 - 3 } & & SRI & Conventional \\
\hline Inbred (NSIC Rc216) & $7.88 \mathrm{a}$ & $7.03 \mathrm{a}$ \\
Hybrid (SL -18H) & $10.91 \mathrm{a}$ & $6.57 \mathrm{~b}$ \\
\hline
\end{tabular}

Means followed by a common letter(s) across production system and variety are not significantly different at $5 \%$ level, HSD.

\section{Yield and Yield Components}

Statistical analysis revealed that the number of productive tillers, and weight of 1,000 grains were significantly influenced by the production system, variety, and level of $\mathrm{N}$ fertilizer application. However, grain yield was only significantly affected by the $\mathrm{N}$ application (Table 5).

Table 5. Yield and yield components of lowland rice as influenced by production system, variety, and $\mathrm{N}$ application

\begin{tabular}{|c|c|c|c|}
\hline Treatment & $\begin{array}{c}\text { No. of productive } \\
\text { tillers hill }^{-1} \text { at maturity }\end{array}$ & $\begin{array}{l}\text { Weight of } 1,000 \\
\text { grains }(\mathrm{g})\end{array}$ & $\begin{array}{c}\text { Grain yie ld } \\
\left(\mathrm{t} \mathrm{ha}^{-1}\right)\end{array}$ \\
\hline \multicolumn{4}{|l|}{ Production System } \\
\hline SRI & $13.83 \mathrm{a}$ & $30.84 a$ & 5.24 \\
\hline Conventional & $11.33 b$ & $28.27 b$ & 4.68 \\
\hline \multicolumn{4}{|l|}{ Variety } \\
\hline Inbred (NSIC Rc216) & $13.67 \mathrm{a}$ & $28.50 \mathrm{~b}$ & 4.84 \\
\hline Hybrid (SL -18H) & $11.48 b$ & 30.61 a & 5.08 \\
\hline \multicolumn{4}{|l|}{ Levels of nitrogen } \\
\hline $0 \mathrm{~kg} \mathrm{ha}^{-1}$ & $10.58 b$ & $28.46 b$ & $4.14 b$ \\
\hline $90 \mathrm{~kg} \mathrm{ha}^{-1}$ & $14.57 \mathrm{a}$ & $30.66 \mathrm{a}$ & $5.78 \mathrm{a}$ \\
\hline C.V. (\%) & 9.72 & 5.44 & 11.75 \\
\hline
\end{tabular}

Rice plants under SRI significantly produced more productive tillers compared to the conventional production system which could be attributed to the young age of seedlings at transplanting since young seedlings recover much earlier than older seedlings (Patra and Haque 2011; Ali et al 2013). The inbred variety significantly had a greater number of productive tillers when compared to the hybrid variety. Additionally, when lowland rice was applied with $90 \mathrm{~kg} \mathrm{~N} \mathrm{ha}^{-1}$, it significantly produced more productive tillers than those plants without $\mathrm{N}$ application.

In terms of weight of 1,000 grains, hybrid rice grown under SRI and applied with $90 \mathrm{~kg} \mathrm{~N} \mathrm{ha}^{-1}$ achieved the heaviest grains. On the other hand, inbred rice grown under conventional method and without $\mathrm{N}$ application had the lightest grains.

For grain yield, however, lowland rice applied with $90 \mathrm{~kg}$ ha 'obtainedsignificantly higher grain yield than those plants without $\mathrm{N}$ application. This is similar to the findings of the study of Pan et al (2012), which reported that grain yield increased with optimal $\mathrm{N}$ fertilizer application. 


\section{Interaction Effect on the Number of Productive Tillers}

Inbred rice under conventional and SRI fertilized with $90 \mathrm{~kg} \mathrm{~N} \mathrm{ha}^{-1}$ and those without $\mathrm{N}$ produced more productive tillers than that of hybrid rice under SRI with no $\mathrm{N}$ application and in the conventional method with or without $\mathrm{N}$ application (Table 6). Hybrid rice unfertilized with $\mathrm{N}$ in both production systems had less productive tillers. With the addition of $\mathrm{N}$, both varieties were comparable in SRI but in the conventional production system, inbred variety produced more productive tillers than the hybrid variety. More productive tillers in both varieties in SRI could be attributed to younger seedlings which favored tiller formation (Pramanik and Bera 2013). Early transplanting of seedlings enhances tillering (Uphoff 2005; Hossain et al 2008; Pasuquin et al 2008).

Table 6. Interaction between production system $\mathrm{x}$ variety $\mathrm{x} \mathrm{N}$ application on the number of productive tillers $\left(\right.$ hill ${ }^{-1}$ ) of lowland rice

\begin{tabular}{|c|c|c|}
\hline \multirow{2}{*}{ Treatment } & \multicolumn{2}{|c|}{ No. of Productive Tillers } \\
\hline & $0 \mathrm{~kg} \mathrm{~N} \mathrm{ha}^{-1}$ & $90 \mathrm{~kg} \mathrm{~N} \mathrm{ha}^{-1}$ \\
\hline \multicolumn{3}{|l|}{ Production System } \\
\hline \multicolumn{3}{|l|}{ System of Rice Intensification ( SRI) } \\
\hline Inbred (NSIC Rc216) & $13.10 \mathrm{ab}$ & $15.87 \mathrm{a}$ \\
\hline Hybrid (SL-18H) & $9.60 \mathrm{~b}$ & $16.73 \mathrm{a}$ \\
\hline \multicolumn{3}{|l|}{ Conventional } \\
\hline Inbred (NSIC Rc216) & $10.40 \mathrm{ab}$ & $15.30 \mathrm{a}$ \\
\hline Hybrid (SL-18H) & $9.23 b$ & $10.37 \mathrm{~b}$ \\
\hline
\end{tabular}

Means followed by a common letter(s) across production system, variety and levels of nitroge $\mathrm{n}$ are not significantly different at $5 \%$ level, HSD.

\section{Interaction effect on the weight of 1,000 Grains (g)}

The results revealed that 1,000 grains of hybrid rice significantly increased with $90 \mathrm{~kg}$ ha- $^{-} \mathrm{N}$ application. Hybrid rice without $\mathrm{N}$ application had the lightest grain. On the other hand, in inbred rice, $90 \mathrm{~kg} \mathrm{ha}^{-1}$ application did not significantly affect the 1,000grain weight (Table 7).

Interaction effects between production systems and levels of $\mathrm{N}$ showed that the lightest 1,000 grains were observed when lowland rice, regardless of variety, was grown under conventional method applied with $90 \mathrm{~N} \mathrm{~kg} \mathrm{ha}^{-1}$ (Table 8). Those grown under SRI with $90 \mathrm{~N} \mathrm{~kg} \mathrm{ha}^{-1}$ and without $\mathrm{N}$ application are comparable to plants grown under conventional system without $\mathrm{N}$ application. However, a significant decrease in 1,000 grain weight was observed in the conventional method when applied with $90 \mathrm{~kg} \mathrm{~N}^{-1}$. This could be due to the lower $\mathrm{N}$ efficiency under the conventional method since the crop may have used the applied $\mathrm{N}$ in its vegetative parts rather than its reproductive parts. This result is similar to the 


\section{Genotypic Differences and Nitrogen Uptake of Lowland Rice}

findings of Thakur et al (2013) that increased $\mathrm{N}$ application decreased grain weight in conventionally grown rice. On the other hand, the heavier 1,000 grains in SRI plants applied with $90 \mathrm{~kg} \mathrm{~N} \mathrm{ha}^{-1}$ could be attributed to more assimilates translocated for grain development. This result conforms to the findings of Sorour et al (2016) and Gewaily et al (2018) that nitrogen fertilizer promoted grain filling during the reproductive stage.

Table 7. Interaction effect between variety and $\mathrm{N}$ application on the weight of 1,000 grains

\begin{tabular}{|c|c|c|}
\hline \multirow{2}{*}{ Variety } & \multicolumn{2}{|c|}{ Weight of 1,000 grains $(\mathrm{g})$} \\
\hline & $0 \mathrm{Nkgha}^{-1}$ & $90 \mathrm{Nkgha}^{-1}$ \\
\hline Inbred (NSIC Rc216) & $28.76 a$ & $28.24 a$ \\
\hline Hybrid (SL -18H) & $28.15 b$ & $33.07 \mathrm{a}$ \\
\hline
\end{tabular}

Means followed by a common letter(s) across variety and levels of nitrogen are not significantly different at $5 \%$ level, HSD.

Table 8. Interaction between production system and $\mathrm{N}$ application on the weight of 1,000 grains

Levels of $\mathrm{N}$

$$
\text { Weight of } 1,000 \text { grains }(\mathrm{g})
$$

$$
\text { SRI Convent ional }
$$

\begin{tabular}{lll}
\hline $0 \mathrm{Nkgha}^{-1}$ & $28.28 \mathrm{a}$ & $28.63 \mathrm{a}$ \\
$90 \mathrm{~N} \mathrm{~kg} \mathrm{ha}^{-1}$ & $33.41 \mathrm{a}$ & $27.91 \mathrm{~b}$
\end{tabular}

Means followed by a common letter(s) across production system and levels of nitrogen are not significantly different at $5 \%$ level, HSD.

\section{Interaction effect on grain yield (tha $\left.{ }^{-1}\right)$}

Grain yield $\left(\mathrm{t} \mathrm{ha}^{-1}\right)$ of lowland rice was influenced by the interaction of variety $\mathrm{x}$ application as well as production system $x \mathrm{~N}$ application (Tables 9 and 10). Inbred and hybrid rice had comparable grain yield when applied with $90 \mathrm{~N} \mathrm{~kg} \mathrm{ha}^{-1}$ regardless of production system. However, grain yield of the hybrid variety was significantly higher than the inbred variety even without $\mathrm{N}$ application (Table 9).

Table 9. Interaction effect between variety and $\mathrm{N}$ application on grain yield of lowland rice

\begin{tabular}{lccc}
\hline & \multirow{2}{*}{ Variety } & \multicolumn{2}{c}{ Grain Yield (t ha ${ }^{-1}$ ) } \\
\cline { 2 - 4 } & & N kg ka $^{-1}$ & $90 \mathrm{Nkg} \mathrm{ha}^{-1}$ \\
\hline Inbred(NSIC Rc216) & $3.76 \mathrm{~b}$ & $5.93 \mathrm{a}$ \\
Hybrid(SL -18H) & $4.52 \mathrm{a}$ & $5.63 \mathrm{a}$ \\
\hline
\end{tabular}

Means followed by a common letter(s) across variety and levels of nitrogen are not significantly different at $5 \%$ level, $\mathrm{HSD}$. 
On the other hand, higher grain yield of lowland rice regardless of variety was observed in plants applied with $90 \mathrm{~N} \mathrm{~kg} \mathrm{ha}^{-1}$ in both production systems. Rice without $\mathrm{N}$ application had the lowest yield (Table 10). This might be due to the readily available source of $\mathrm{N}$ that is taken up by the plants for grain production. This result conformed with the findings of Singh et al (2000) that increase in grain yield was directly related to nitrogen application which enhanced the vegetative growth and grain formation and development.

Rice in SRI and conventional systems and applied with $90 \mathrm{~N} \mathrm{~kg} \mathrm{ha}{ }^{-1}$ had significantly higher grain yields than those without $\mathrm{N}$ fertilizer. Higher yields could be attributed to the availability of applied $\mathrm{N}$ throughout the growth cycle of the crop that resulted in more productive tillers and filled grains per panicle.

Table 10. Interaction effect between production system and level of $\mathrm{N}$ on the grain yield of lowland rice

\begin{tabular}{lcc}
\hline \multirow{2}{*}{ Production System } & \multicolumn{2}{c}{ Grain Yield (t ha $\left.{ }^{-1}\right)$} \\
\cline { 2 - 3 } & $0 \mathrm{Nkg} \mathrm{ha}^{-1}$ & $90 \mathrm{Nkg} \mathrm{ha}^{-1}$ \\
\hline SRI & $4.14 \mathrm{~b}$ & $6.35 \mathrm{a}$ \\
Conventional & $4.14 \mathrm{~b}$ & $5.21 \mathrm{a}$ \\
\hline
\end{tabular}

Means followed by a common letter(s) across production system and levels of nitrogen are not significantly different at $5 \%$ level, HSD.

\section{Nitrogen Use Efficiency (NUE)}

Nitrogen use efficiency is the ratio between the level of $\mathrm{N}$ fertilizer applied and the amount of $\mathrm{N}$ removed by the biomass. Statistical analysis revealed that total aboveground plant $\mathrm{N}$ uptake (TNU) was affected by $\mathrm{N}$ application but not by the production system and variety (Table 11).

Regardless of production system and variety, plants applied with $90 \mathrm{~N} \mathrm{~kg} \mathrm{ha}^{-1}$ significantly obtained higher TNU compared to those without $\mathrm{N}$. This increase in TNU could be attributed to utilization of applied N. This result conforms with the findings of Singh et al (1998), that plant $\mathrm{N}$ uptake increases with $\mathrm{N}$ supply in most rice varieties.

In terms of NUE, plants without N significantly obtained higher NUE compared to $\mathrm{N}$ fertilized plants regardless of variety and production system. This result reflects that the higher NUE resulted in a significantly lower TNU. Plants fertilized with $90 \mathrm{~N} \mathrm{~kg} \mathrm{ha-1}$ had significantly lower NUE, which shows that TNU and NUE is inversely proportional with each other. This suggests a greater $\mathrm{N}$ uptake but less accumulation of biomass, which indicates a crop's capacity for luxurious $\mathrm{N}$ uptake (Robinson et al 2014; Wang and Peng 2017). 
Table 11. Nitrogen use efficiency of lowland rice as influenced by production system, variety, and $\mathrm{N}$ application

\begin{tabular}{lcc}
\hline \multicolumn{1}{c}{ Treatment } & $\begin{array}{c}\text { TNU } \\
\left(\mathrm{kg} \mathrm{ha}^{-1}\right)\end{array}$ & $\begin{array}{c}\mathrm{NUE} \\
\left(\mathrm{kg} \mathrm{kg}^{-1}\right)\end{array}$ \\
\hline Production System & 114.74 & 44.22 \\
$\quad$ System of Rice Intensification (SRI) & 107.16 & 45.89 \\
$\quad$ Conventional & & \\
Variety & 109.20 & 44.73 \\
$\quad$ Inbred (NSIC Rc216) & 112.71 & 45.38 \\
$\quad$ Hybrid (SL -18H) & & \\
Levels of N & $83.83 \mathrm{~b}$ & $48.91 \mathrm{a}$ \\
O N kg ha ${ }^{-1}$ & $138.08 \mathrm{a}$ & $41.20 \mathrm{~b}$ \\
$\quad$ 90 N kg ha ${ }^{-1}$ & 19.31 & 9.86 \\
\hline C.V. (\%)
\end{tabular}

Means within a column with the same letter(s) are not significantly different at $5 \%$ level, HSD.

\section{Interaction Effect of production system and $\mathbf{N}$ application on Internal or Physiological N Use Efficiency (NUE)}

The statistical analysis revealed that plants applied with or without $\mathrm{N}$, regardless of variety, had higher NUE under SRI. However, under conventional production system, application of $90 \mathrm{~N} \mathrm{~kg} \mathrm{ha}^{-1}$ significantly reduced NUE (Table 12). The decrease in NUE in plants applied with $90 \mathrm{~N} \mathrm{~kg} \mathrm{ha}^{-1}$ grown under conventional production system could be caused by $\mathrm{N}$ loss due to volatilization, leaching, and runoff. This result further conforms to the findings of Wang and Peng (2017) that NUE decreases with increased $\mathrm{N}$ fertilizer application.

Table 12. Interaction effect between production system and $\mathrm{N}$ application on Nitrogen Use Efficiency (NUE) of lowland rice

\begin{tabular}{lccc}
\hline \multirow{2}{*}{ Level of $\mathrm{N}$} & \multicolumn{2}{c}{$\mathrm{NUE}\left(\mathrm{kg} \mathrm{kg}^{-1}\right)$} \\
\cline { 2 - 4 } & & $\mathrm{SRI}$ & Conventional \\
\hline $0 \mathrm{~N} \mathrm{~kg} \mathrm{ha}^{-1}$ & $43.66 \mathrm{a}$ & $54.15 \mathrm{a}$ \\
$90 \mathrm{~N} \mathrm{~kg} \mathrm{ha}^{-1}$ & & $44.77 \mathrm{a}$ & $37.62 \mathrm{~b}$ \\
\hline
\end{tabular}

Means followed by a common letter(s) across production system and levels of nitrogen are not significantly different at $5 \%$ level, HSD.

\section{CONCLUSION}

Results of this study showed that water supplied in plants under SRI was reduced by $32 \%$ due to alternate wetting and drying (AWD). AWD also enhanced RPR in SRI due to a greater number of tillers per hill. Inbred rice grown in SRI headed and matured earlier than those in the conventional system. Hybrid rice significantly grew taller regardless of production system when applied with $90 \mathrm{~N} \mathrm{~kg} \mathrm{ha}^{-1}$.In terms of LAl, lowland rice grown under SRI significantly had higher LAI values than those grown under the conventional production system. Interaction effect between 
production system, variety, and $\mathrm{N}$ application showed that lowland rice grown under SRI fertilized with $90 \mathrm{~N} \mathrm{~kg} \mathrm{ha-1} \mathrm{had} \mathrm{more} \mathrm{tillers} \mathrm{per} \mathrm{hill.} \mathrm{Regardless} \mathrm{of} \mathrm{production}$ system and variety, lowland rice yielded higher in $90 \mathrm{~N} \mathrm{~kg} \mathrm{ha}^{-1}$ plots. This implies that grain yield is comparable in both SRI and conventional production system. In terms of NUE, plants without $\mathrm{N}$ application attained a higher value than those fertilized with $90 \mathrm{~N} \mathrm{~kg} \mathrm{ha}^{-1}$. However, interaction effect between production system and level of $\mathrm{N}$ showed that plants grown under SRI applied with $90 \mathrm{~N} \mathrm{~kg} \mathrm{ha}^{-1}$ had higher NUE.

\section{REFERENCES}

Ali MS, Hasan MA, Sikder S, Islam MR \& Hafiz MHR. 2013. Effect of Seedling Age and Water Management on the Performance of Boro Rice (Oryza sativa L.) Variety BRRI Dhan 28. Agriculturist. 11,28-37

Barison Jand Uphoff N.2011. Rice yield and its relation to root growth and nutrientuse efficiency under SRI and conventional cultivation: An evaluation in Madagascar. Paddy and Water Environment. 9(1),65-78.

Chaturvedi I. 2005. Effect of nitrogenous fertilizers on growth, yield and quality of hybrid rice. J Cent Europ Agri. 4,611.

Gewaily EE, Ghoneim AM \& Osman MMA.2018. Effects of nitrogen levels on growth, yield and nitrogen use efficiency of some newly released Egyptian rice genotypes. Open Agriculture.3,310-318

Gomez KA and Gomez AA.1984. Statistical Procedures for Agricultural Research. 2nd eds. John Wiley and Sons, New York, USA.

Haefele SM, Naklang K, Harnpichitvitaya D, Jearakongman S, Skulkhu E, Romyen P, Phasopa S, Tabtim S, Suriya-arunroj D, Khunthasuvon S, Kraisorakul D, Youngsuk P, Amarante ST \& Wade LJ. 2006. Factors affecting rice yield and fertilizer response in rainfed lowlands of northeast Thailand. Field Crops Research. 98(1),39-51

Haque MM, Pramanik HR, Biswas JK, Iftekharuddaula KM \& Hasanuzzaman M. 2015. Comparative performance of hybrid and elite inbred rice varieties with respect to their source-sink relationship. The Scientific World Journal.11 pages.

Hossain MZ, Sarkar MAR \& Islam AKMM. 2008. Effect of age of seedlings and date of transplanting on the performance of Bororice under SRI method. Bangladesh J. Crop. Sci. 19(1),21-26.

Huang M, Xia B, Zou Y, Jiang P, Shi W, Hongthong P \& Xie X. 2012. Improvement in super hybrid rice: A comparative study between super hybrid and inbred varieties. Res. on Cops. 13(1), 1-10.

Hütsch BW and Schubert S. 2017. Chapter Two - Harvest Index of Maize (Zea mays L.): Are there possibilities for improvement? Advances in Agronomy. 146,3782.

ISRIC (INTERNATIONAL SOIL REFERENCE INFORMATION CENTER) 1995. Procedure for soil analysis. (L.P. Van Reeuwijk, Editor) Wageningen, the Netherlands. p. 106.

Jehangir WA, Masih I, Ahmed S, Gill MA, Ahmad M, Mann RA, Chaudhary MR, Qureshi AS \& Turral H.2007. Sustaining crop water productivity in rice-wheat systems of South Asia: A case study from the Punjab, Pakistan. International 
Water Management Institute, Colombo, Sri Lanka.

Jing Q, Dai T, Jiang D, ZhuY \& Cao W. 2007. Spatial distribution of leaf area index and leaf $\mathrm{N}$ content in relation to grain yield and nitrogen uptake in rice. Plant Production Science. 10(1), 136-145.

Krupakar Reddy G. 2004. Varietal performance and spatial requirement of rice under System of Rice Intensification during Kharif season. M.Sc (Ag.) Thesis. Acharya N.G. Ranga Agricultural University, Hyderabad, India.

Kumar G. 2014. Evaluation of system of rice intensification (SRI) for enhanced seed yield and quality. M.Sc (Ag.) Thesis. Acharya N.G. Ranga Agricultural University, Hyderabad, India.

Landon JR. 1991. Booker tropical soil manual: A handbook for soil survey and agricultural land evaluation in the tropics and subtropics. Paperback edition, London.

Liu Q, Zhou X, Li J \& Jingling L. 2017. Effects of seedling age and cultivation density on agronomic characteristics and grain yield of mechanically transplanted rice. Sci Rep 7, 14072 (2017)

Moro BM, Nuhu IR, Ato E \& Nathanial B. 2015. Effects of nitrogen rates on the growth and yield of three rice (Oryza sativa L.) varieties in rain-fed lowland in the forest agro-ecological zone of Ghana. International Journal of Agricultural Sciences. 5(7),878-885.

Nelson DW and Sommers LE. 1982. Methods of Soil Analysis, Part 2. American Society of Agronomy-Soil Science Society of America, 677 South, Segoe Road, Madison, WI 53711, USA.

O'toole JC and Soemartono. 1981. Evaluation of a simple technique for characterizing rice root systems in relation to drought resistance. Euphytica. 30(2), 283-290.

Olsen S, Cole C, Watanabe F \& Dean L. 1954. Estimation of available phosphorus in soils by extraction with sodium bicarbonate. USDA Circular Nr 939, US Gov. Print. Office, Washington, D.C.

Pan S, Huang S, Zhai J, Wang J, Cao C, Cai M, Zhan M \& Tang X. 2012. Effects of N Management on Yield and $\mathrm{N}$ uptake or rice in Central China. Journal of Integrative Agriculture. 11(12),1993-2000.

Pasuquin E, Lafarge T \& Tubana B. 2008. Transplanting young seedlings in irrigated rice fields: Early and high tiller production enhanced grain yield. Field Crops Research. 105(1-2),141-155.

Patra PS and Haque S. 2011. Effect of Seedling Age on Tillering Pattern and Yield of Rice (Oryza sativa L.) under System of Rice Intensification. ARPN Journal of Agricultural and Biological Sciences. 6,33-35.

Pramanik K and Bera A. 2013. Effect of Seedling Age and Nitrogen Fertilizer on Growth, Chlorophyll Content, Yield and Economics of Hybrid Rice (Oryza sativa L.). International Journal of Agronomy and Plant Production. 4,34893499.

PCARR. 1980. Standard methods for soil, plant tissue, water and fertilizer. Farm and Systems Res. Div. Philippine Council for Research and Agriculture. Los Baños. p. 164.

Rahaman M. 2004. Response of photosensitive rice to nitrogen levels in boro season. Oryza. 41,101-104.

Rathnayake WMUK, De Silva RP \& Dayawansa NDK. 2016. Assessment of the 
suitability of temperature and relative humidity for rice cultivation in rainfed lowland paddy fields in Kurunegala district. Tropical Agricultural Research. 27(4), 370-388.

Redfern SK, Azzu N \& Binamira JS. 2012. Rice in Southeast Asia: facing risks and vulnerabilities to respond to climate change. In Meybeck A, Lankoski J, Redfern S, Azzu N \& Gitz V. (eds) Building Resilience for Adaptation To Climate Change In The Agriculture Sector: Proceedings of a Joint FAO/OECD Workshop 23-24 April 2012. FAO.

Robinson N, Vog TJ, Lakshmanan P \& Schmidt S. 2014. Sugarcane: Physiology, Biochemistry, and Functional Biology. $1^{\text {st }}$ edn. John Wiley and Sons, Inc.

Satyanarayana A, Thiyagarajan TM \& Uphoff N. 2007. Opportunities for water saving with higher yield from the system of rice intensification. Irrig. Sci. 25:99-115.

Singh U, Ladha JK, Castillo EG, Punzalan G, Tirol-Padre A \& Duqueza M. 1998. Genotypic variation in nitrogen use efficiency in medium- and long-duration rice. Field Crops Research. 58,35-53.

Singh MK, Thakur R, Verma UN \& Upasani RR. 2000. Effect of planting time and nitrogen on production potential of Basmati rice (Oryza sativa L.) cultivars in Bihar Plateay. Ind. J. Agronomy. 45, 300-303.

Shi Q, Zeng X, Li M, Tan X, \& Xu F. 2002. Effect of different water management practice on rice growth. In: Bouman, B.A.M. et al. (Eds.), Water Wise Rice Production. IRRI, Los Baños, Philippines, pp. 3-13.

Somasundaram E, Velayutham A, Poonguzhalan R \& Sathiyavelu A. 2002. Effect of nitrogen levels on growth and yield of rice (SSRC 91216, TRY 2) under sodic soil condition. Mad Agric J. 89, 506-508.

Sorour FA, Ragab AY, Metwally TF \& Shafik AA. 2016. Effect of planting methods and nitrogen fertilizer rates on the productivity of rice (Oryza sativa L.). J. Plant. Prod. 42, 207-216.

Thakur AK, Rath S \& Mandal KG. 2013. Differential response of system of rice intensification (SRI) and conventional flooded-rice management methods to applications of nitrogen fertilizer. Plant Soil. 370(1/2), 59-71.

Trivedi PC. 2006. Advances in Plant Physiology. I.K. International Pvt Ltd.

Uphoff N, Ball AS, Fernandez E, Herren H, Husson O, Laing M, Palm C, Pretty J, Sanchez P, Sanging N \& Thies J. 2006. Biological Approaches to Sustainable Soil Systems. CRC Press, Taylor and Francis Group. Boca Raton, FL.

Wang F \& Peng S. 2017. Yield potential and nitrogen use efficiency of China's super rice. Journal of Integrative Agriculture. 16(5), 1000-1008.

Wood S, Henao J \& Rosegrant M.2004. The role of nitrogen in sustaining food production and estimating future nitrogen fertilizer needs to meet food demand. In Agriculture and the Nitrogen Cycle: Assessing the Impacts of Fertilizer Use on Food Production and the Environment (A. R. Mosier, J. K. Syers, and J. R. Freney, Eds.), SCOPE 65, Paris, France,pp. 245-260.

Wu M, Liu M, Liu J, Li W, Jiang C \& Li Z. 2017. Optimize nitrogen fertilization location in root-growing zone to increase grain yield and nitrogen use efficiency of transplanted rice in subtropical China. Journal of Integrative Agriulture. 16(9), 2073-2081.

Yin X, Kroff MJ \& Goudriann J. 1996. Differential effects of day and night temperature on development to flowering in rice. Annals of Botany. 77, 203- 


\section{Genotypic Differences and Nitrogen Uptake of Lowland Rice}

213.

Yoshida S, Forna DA, Cock JH \& Gomez KA. 1976. Laboratory Manual for Physiological Studies of Rice. 3rd eds. International Rice Research Institute, Los Baños, Laguna, Philippines. p. 27.

Yoshida S. 1981. Fundamental of Rice Crop Science. International Rice Research Institute, Los Baños, Laguna, Philippines, p. 269.

Zhang $\mathrm{H}$, Xue Y, Wang Z, Yang J, \& Zhang J. 2009. An alternate wetting and moderate soil drying regime improves root and shoot growth in rice. Crop Sci. 49:2246-2260.

Zhang Y, Xu J, Cheng Y, Wang C, Liu G\& Yang J. 2020. The effect of water and nitrogen on the roots and yield of upland and paddy rice. Journal of Integrative Agriculture. 19(5), 1363-1374.

Zhao LM, Wu LH, LiY S, Lu XH, Zhu DF \& Uphoff N.2009. Influence of the System of Rice Intensification on rice yield and nitrogen and water use efficiency with different $\mathrm{N}$ application rates. Exp Agric. 45,275-286 